Evolution of the financial sector - three different stages:

Repression, development and financialisation

Ricardo Barradas

Dezembro de 2015

WP n. ${ }^{\circ} 2015 / 08$

DOCUMENTO DE TRABALHO

WORKING PAPER

DINAMIA'CET

IECTE-ax 


\section{DINAMIR'CET}

SOCTIOECONOR

Evolution of the financial sector - three different stages:

Repression, development and financialisation

Ricardo Barradas *

WP n. ${ }^{\circ} 2015 / 08$

DOI: $10.15847 /$ dinamiacet-iul.wp.2015.08

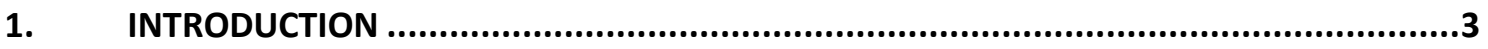

2. FROM FINANCIAL REPRESSION TO FINANCIAL DEVELOPMENT ..............................

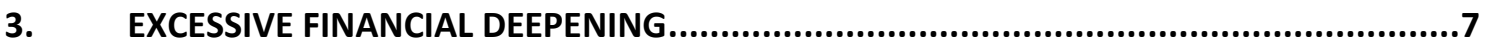

4. THE CONCEPT AND THE EMERGENCE OF FINANCIALISATION .................................10

5. FEATURES AND EFFECTS OF THE FINANCIALISATION PROCESS............................13

6. POLICY IMPLICATIONS AND THE NEED TO DE-FINANCIALISATION............................25

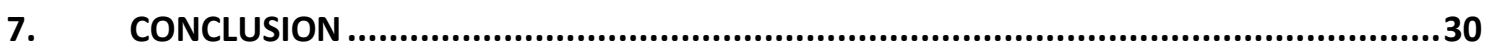

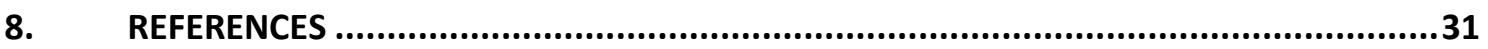

* rbarradas@escs.ipl.pt / rpbarradas@iscal.ipl.pt; DINÂMIA'CET - IUL and Instituto Universitário de Lisboa (ISCTE-IUL); Higher School of Communication and Media Studies (Polytechnic Institute of Lisbon) Higher Institute of Accounting and Administration of Lisbon (Polytechnic Institute of Lisbon) 


\title{
Evolution of the financial sector - three different stages: Repression, development and financialisation ${ }^{1}$
}

\begin{abstract}
This paper makes a systematic literature review on the evolution of the financial sector in the last decades all over the world, but especially in the more developed countries. This evolution was marked by three different stages, reflecting different impacts of the financial sector on the real economy and on society. The first stage - financial repression - is characterised by the existence of several regulations and restrictions on the financial sector, which proved to be detrimental to support economic growth. This legitimised the financial liberalisation and deregulation of the financial sector in the recent years, representing the second stage - financial development. Consequently, there was a strong growth of the financial sector in subsequent years, originating an excessive financial deepening and casting doubts around the advantages provided by the financial sector. In fact, excessive financial deepening weakened or reversed the relationship between savings and investments. The large growth of the financial sector and its deleterious effects are commonly referred as financialisation, constituting the third stage. The paper concludes that it is necessary to engage in a fourth stage in the coming years - definancialisation - in order to re-establish a more supportive relationship between the financial sector and economic growth and presents several policy recommendations around this matter.
\end{abstract}

\section{KEYWORDS}

Financial Repression, Financial Liberalisation and Deregulation, Financial Development, Excessive Financial Deepening, Financialisation, De-Financialisation

\section{JEL CLASSIFICATION}

E44 and G10

\footnotetext{
${ }^{1}$ The author is grateful for the helpful comments and suggestions from Sérgio Lagoa. The usual disclaimer applies.

DINÂMIA'CET - IUL, Centro de Estudos sobre a Mudança Socioeconómica e o Território ISCTE-IUL - Av. das Forças Armadas, 1649-026 Lisboa, PORTUGAL 


\section{INTRODUCTION}

This paper presents a state of art around the evolution of the financial sector in the majority of economies in the last decades. This evolution was marked by three different stages: financial repression, financial development, and financialisation. Each stage is associated with a different impact of the financial sector in the real economy or in society.

The first stage - financial repression - was characterised by strong regulations and restrictions on the functioning of financial markets and banking activity, namely on the level of interest rates (paid on deposits and charged on loans), products that can be supplied by financial institutions, and volume, direction and allocation of credit. In some countries, the majority of financial institutions were State-owned or State-directed.

Nonetheless, a strong liberalisation and deregulation of the financial sector took place in the 1980s, given rise to the second stage - financial development. This new deregulatory framework was supported by theoretical arguments of the advantages provided by the financial sector, namely on the positive impact of financial development on savings and investments. This was also corroborated by the emergence of several empirical studies, finding a positive relationship between financial development and economic growth. As a result, regulations were slackened, ceilings on interest rates removed, reserve requirements lowered, international capital controls eliminated and some financial institutions privatised.

The process of liberalisation and deregulation resulted in a huge growth of the financial system in relation to savings and investments, not only in terms of deposits, loans and stock markets, but also in relation to derivatives, securitisation and shadow banking system. Hence, an excessive financial deepening was originated, which implied a decrease or a reversal in the relationship between financial development and economic growth. This corresponds to the third stage of the evolution of the financial sector - financialisation - that could be referred as the negative impacts of the strong growth of the financial sector on the real economy, economic agents and macroeconomic outcomes ${ }^{2}$. There is no consensus in relation to the concept of financialisation, but all of them offer a negative perspective on the impact of growth of finance in the economy, contrary to the predictions of mainstream economics that considers the growth of finance as a general positive phenomenon.

Against this backdrop, the literature on financialisation advocates that it is necessary to engage in a fourth stage - de-financialisation - in order to re-establish a more supportive relationship between the financial system and the real economy. Policy makers should therefore

\footnotetext{
2 However, it is worth to note that the second stage - financial development - is not totally independent of the third stage - financialisation. In fact, the financial development could be viewed as the beginning of the financialisation process, namely through the financial liberalisation and the respective deregulation that favoured the huge growth of the financial sector in the subsequent years.
} 
promote a higher sustainability of the financial system that could be more conductive to economic growth, employment, quality of jobs, equality, and human development.

The remainder of the paper is organised as follows. Section 2 presents the main theoretical and empirical arguments that are used to support financial development, and liberalisation and deregulation of the financial sector. Some negative effects resulting from that liberalisation process are highlighted in Section 3. In Section 4, the concept of financialisation and the conditions that favoured its emergence are discussed. Section 5 presents the main features and effects related with the financialisation process all over the world. Section 6 suggests a set of policy recommendations in order to contour the deleterious effects of financialisation. Finally, Section 7 concludes.

\section{FROM FINANCIAL REPRESSION TO FINANCIAL DEVELOPMENT}

It is widely acknowledged that a proper financial sector plays a crucial role in any economy, functioning like a motor to economic growth, social progress and general development. In fact, the belief that "financial markets contribute to economic growth is a proposition too obvious for serious discussion" (Miller, 1998, p. 14). Hein (2009) also recognises that it is "broadly accepted that the development of the financial sector of an economy is crucial for real economic growth" (Hein, 2009, p. 2).

This argument has been used to support the financial development during the last decades, visible in the growth of the financial sector and in the emergence of new financial instruments, financial institutions and financial markets, which aim to support economic growth. In the view of Sawyer (2014), financial development can be viewed as the growth and evolution of the financial sector (in terms of deposits, loans and stock markets), upward changes in the scale of the financial sector and financial innovations.

As suggested by Sawyer (2014), the positive relationship between the development of the financial sector and economic growth is related with the effects of the financial sector on savings, investment funding and the quality of investment. According to this author, the financial sector has two main functions that are indispensable for economic growth, namely the reallocation of savings towards the funding of investment.

Effectively, Schumpeter (1911) had already noted that a necessary element for innovations is the ability of the financial sector to extend credit to the entrepreneurs. He argues that somebody could only become an entrepreneur if previously have becoming a debtor, since entrepreneurs need credit (or other forms of funding) to materialize their innovations.

DINÂMIA'CET - IUL, Centro de Estudos sobre a Mudança Socioeconómica e o Território ISCTE-IUL - Av. das Forças Armadas, 1649-026 Lisboa, PORTUGAL 


\section{Evolution of the financial sector - three different stages: \\ Repression, development and financialisation}

In the same fashion, Levine (2005) emphasises that the financial sector is crucial to promote economic growth, since it produces information ex ante about investments; allocates capital; monitors investments; exerts corporate governance after providing funding; facilitates the trading of both financial and non-financial assets; offers diversification of risk and risk management services; mobilizes and pools savings to finance investments; and eases the exchange of goods and services.

Palley (2007) adds that conventional economic theory also supports the growth of the financial sector due to five essential reasons. Firstly, conventional economic theory looks at the relationship between corporations and financial markets in terms of an agency problem (Jensen and Meckling, 1976), advocating that "shareholder value orientation" is the appropriate and logical goal of corporations. Secondly, conventional economic theory considers financial assets as contingent claims (Arrow and Debreu, 1954). According to this view, finance enhances efficiency since financial markets help to foresee future economic outcomes and allow economic agents to assemble portfolios with better combinations of returns and risk. Thirdly, conventional economic theory refers to Friedman's (1953) argument that financial speculation is stabilizing by driving prices back to the level warranted by their fundamentals. Fourthly, conventional economic theory highlights that increased trade volumes rises market liquidity and therefore market prices are less susceptible to small random disturbances or manipulations by individual participants. Fifthly, conventional economic theory tends to consider that the development of the financial sector induces investments by corporations when the market price of capital is higher than its replacement cost (theory of Tobin's q), which provides an indication that capital is scarce and that profitable investment opportunities are available.

Similarly, Orhangazi (2008a) highlights that conventional economic theory claims that the financial sector is fundamental to promote investments by corporations by providing funding, increasing the efficiency in resources allocation by screening and monitoring investments, removing market imperfections, reducing transaction costs and providing risk management services.

On one hand, the claims of mainstream economics on the advantages provided by the financial sector operated as a motto to legitimise the financial liberalisation and deregulation of the financial sector in the last decades. As recognised by Stockhammer (2010), supporters of financial liberalisation and deregulation argue that they are beneficial by providing a superior way of dealing with risk. In fact, they make the financial system more stable and society better off (International Monetary Fund (IMF), 2006). Stockhammer (2010) gives the example of securitisation, which allowed to split the risk into different parts and allocate them to those who were best equipped to hold them.

DINÂMIA'CET - IUL, Centro de Estudos sobre a Mudança Socioeconómica e o Território ISCTE-IUL - Av. das Forças Armadas, 1649-026 Lisboa, PORTUGAL 
On the other hand, the emergence of several empirical studies finding a positive relationship between financial development and economic growth also seems to have contributed to accelerate financial liberalisation and deregulation (Sawyer, 2013a and 2014).

Levine (2005) refers that a growing body of empirical literature through corporationlevel studies, industry-level studies, individual-country studies, panel data studies and broad cross-country comparisons demonstrates a strong positive relationship between the good functioning of the financial system and the long-term economic growth. Ang (2008) surveys the main results of cross-country studies, finding that the majority of them indicate that the financial sector exerts a positive effect on economic growth. Arestis et al. (2015) conduct a meta-analysis on the existing empirical literature on the effects of financial development on economic growth, finding that there is a statistically significant and positive effect of financial development on economic growth.

Overall, this contributes to construct the thesis that financial repression, characterized by several regulations and restrictions on financial markets and on the banking system, is detrimental to economic development since they restrain the quantity and quality of investments (Mckinnon, 1973; and Shaw, 1973).

According to Sawyer (2014), financial repression is commonly referred as a stronger regulation of the financial and banking systems in many countries, which typically involves the direct control by the central bank or by the government of the level of interest rates that can be charged on loans or paid on deposits, the products that can be supplied by banks (or other financial institutions) and the volume, direction and allocation of credit.

Epstein (2005a) also notes that financial repression involved financial regulations and State-owned or State-directed banks that were used to support a wide range of economic and social purposes. He adds that central banks in developed and developing countries imposed some regulations on financial institutions in order to direct credit to specific sectors.

Thus, a period of financial repression gave rise to a period of financial liberalisation in order to achieve a higher development of the financial sector that could contribute to higher levels of economic growth. Financial liberalisation implied internal and external measures, like the elimination of regulations, removal of interest rates ceilings, the reduction of reserve requirements, the abolition of directed credit programmes and the elimination of capital controls (Sawyer, 2014 and 2015). Sawyer notes that this process implied an upward adjustment of the real interest rates to its equilibrium levels. So, the allocation of credit would be set by the free market, which would guarantee that investment projects with low returns would be eliminated contributing to increase the levels of efficiency. In the same vein, the increase of real interest rates and the lower reserve requirements would allow a rise in savings and an increase in the

DINÂMIA'CET - IUL, Centro de Estudos sobre a Mudança Socioeconómica e o Território ISCTE-IUL - Av. das Forças Armadas, 1649-026 Lisboa, PORTUGAL 
supply of credit, which would induce higher volumes of investment and therefore higher levels of economic growth and more employment creation.

Effectively, Demir (2009) agrees that financial liberalisation favours the growth of capital markets, reduces agency costs, decreases the asymmetry of information and increases the levels of efficiency. He claims that this process could exacerbate a transfer of savings to more efficient projects at lower costs, which is expected to boost investment and economic growth.

Figure 1 contains the main advantages - referred in the literature - provided by the financial sector, which legitimated the adoption of several measures in order to liberalise and deregulate the financial sector.

Figure 1 - Main advantages provided by the financial sector

\begin{tabular}{l|l} 
& $\begin{array}{l}\text { Transfers funds from savers to borrowers (i.e. the intermediation process) } \\
\text { Provides credit to entrepreneurs } \\
\text { Produces information } \text { ex ante about investments } \\
\text { Monitors investments }\end{array}$ \\
Advantages of the financial sector & $\begin{array}{l}\text { Facilitates the diversification of risk } \\
\text { Provides a superior way of dealing with risk } \\
\text { Provides risk management services }\end{array}$ \\
Increases efficiency by foreseeing future economic outcomes \\
Financial speculation it is considered as stabilizing \\
Rises market liquidity
\end{tabular}

Source: Authors' representation

Against this backdrop, the realm of finance acquired a great prominence in the most developed economies in the last three decades, fuelling the popular perception that finance is increasingly dominating the real activity and the everyday life of citizens (e.g. Krippner, 2005 and 2011; Epstein, 2005b; Palley, 2007; Orhangazi, 2008a; Davis, 2009; and Stockhammer, 2010), such that "it is difficult to escape the impression that we live in a world of finance" (Krippner, 2005, p. 173).

\section{EXCESSIVE FINANCIAL DEEPENING}

Nonetheless, Kose et al. (2006) and Prasad et al. (2007) found little evidence that financial liberalisation conducted to a best economic performance all over the world, adding that further research should be carried out in order to derive policy conclusions regarding the effects of the deregulation of finance, mainly with respect to foreign capital inflows.

Indeed, the size of financial sector, traditionally measured by the importance of bank deposits and/or by the stock market valuation in relation to GDP, rose expressively in the recent years, increasing fears that it can became too large and increasing doubts on the positive "finance-growth nexus" (Sawyer, 2014). He recognises that the growth of the financial sector 


\section{Evolution of the financial sector - three different stages: \\ Repression, development and financialisation}

has not been associated with a faster economic growth, which was somewhat slower over the past three decades in Western industrialised economies.

Rousseau and Wachtel (2011) also refer that the relationship between financial development and economic growth weakened in the last years. They even recognise that this relationship is now not as strong as until the end of 1990s, presenting several explanations for that. First, they state that the incidence of financial crises is related to the dampening of the effect of financial development on the economic growth. Second, they conclude that the rapid growth of credit led to inflation episodes and weakened banking systems. Thirdly, they argue that the excessive financial development could be a result of widespread financial liberalisation since the 1980s accompanied by the absence of legal and regulatory infrastructures to support financial development successfully.

Additionally, Cecchetti and Kharroubi (2012) alert that the size of financial sector has an inverted U-shaped effect on economic growth. This means that, from a certain threshold, a further enlargement of the financial sector can reduce real economic growth. Based on a sample of developed and emerging economies, they also find that the growth of the financial sector could be a hurdle to productivity growth, namely because the financial sector competes with the rest of the economy for scarce resources and therefore financial booms are not growth enhancing.

The same conclusion is provided by Dabla-Norris and Srivisal (2013), who refers that the beneficial role of financial deepening in dampening the volatility of consumption, investment and output across countries only occurs up to a certain threshold. They state that the growth of the financial sector to high levels (as those observed in many advanced economies) amplifies the volatility of consumption and investment.

Barajas et al. (2013) also reinforces that there is considerable empirical evidence supporting that there is a positive, but non-linear, relationship between financial deepening, economic growth and macroeconomic volatility. They stress that the strong growth of credit has increased bank fragility and the likelihood of a systemic banking crisis. They still report that Barajas et al. (2012) find evidence of a positive effect of financial development on economic growth among middle-income countries, whilst Rioja and Valev (2004a and 2004b) and Aghion et al. (2005) find a declining effect of financial development on economic growth as countries become richer.

Beck et al. (2014) also confirm that financial systems have grown expressively all over the world, which has occurred simultaneously with a higher volatility of the financial sector in relation to the economy as a whole. Based on a sample of 77 countries for the period between 1980 and 2007, they find that the size of the financial sector (measured by the gross value added

DINÂMIA'CET - IUL, Centro de Estudos sobre a Mudança Socioeconómica e o Território ISCTE-IUL - Av. das Forças Armadas, 1649-026 Lisboa, PORTUGAL 


\section{Evolution of the financial sector - three different stages: \\ Repression, development and financialisation}

of financial activities in total gross domestic product (GDP)) and the level of intermediation (proxied by the natural logarithm of the ratio of credit to GDP) do not have a statistically significant impact on long-term economic growth or on volatility. They also show that the size of the financial sector and the level of intermediation are not associated with higher economic growth in the medium-term in the majority of these countries.

Effectively and as stressed by Sawyer (2014 and 2015), the positive relationship between the financial sector and economic growth has weakened and even reversed in the recent years. He highlights that this relationship could be even more negative, since the majority of empirical works regarding this topic uses bank deposits and/or the size of stock markets as proxies to financial development neglecting other forms of expansion of the financial sector in the last decades related with the proliferation of derivatives, securitisation, shadow banking and the scale of financial asset transactions relative to the levels of savings and investment.

Two traditional explanations are presented to clarify the reversal in the relationship between financial development and economic growth (Sawyer, 2014). The first is related with the idea that financial sector also absorbs resources (often highly paid), which are then not available to real sectors (i.e. non-financial productive sectors). The second is related with the "too big financial sector" hypothesis, according to which the strong growth of the financial sector has weakened the positive link between savings and investments. This happens due to the liquidity function of the financial sector, which could simply induce the exchange of financial assets (i.e. rearrangement of asset portfolios) by savers without generating funds to investors.

Menkhoff and Tolksdorf (2001) also express that there has been a change in the role of the financial sector during the last decades. They advocate that, in the past, the financial sector supported and boosted directly economic growth ("optimistic view"), through a "supportive relationship". Nonetheless, this relationship altered expressively in the last ten or twenty years, and events of the financial sphere started to follow their own logic and, therefore, the real economy began to adapt by itself to the consequences of this. This is the "pessimistic view" regarding the role of the financial sector and the real economy, which has produced a kind of "disruptive relationship" between them, which these authors call the "decoupling hypothesis" between the financial sector and the real economy.

In fact and as recognised by Sawyer (2014), the financial liberalisation exacerbates the instability of the financial system as a whole. As for instance, Freeman (2010) highlights that historical experience in the last few decades illustrates the impact of deregulation of finance, notably in the episode of the United States (US) savings and loan crisis in the 1980s, the Japanese asset-price bubble in the end of 1980s, the Swedish financial crisis in 1992, the collapse of Long-Term Capital Management in 1996, the Asian financial crises in 1997, the 


\section{Evolution of the financial sector - three different stages: \\ Repression, development and financialisation}

'dot.com bubble', the bankruptcy of Lehman Brothers, among other episodes. These events are demonstrations of the unsustainable nature of liberalisation and deregulation of the financial sector and of capital controls.

Figure 2 presents the main problems - appointed by the literature - caused by the strong liberalisation and the respective deregulation of the financial sector in the last decades.

Figure 2 - Main problems caused by the liberalisation and deregulation of the financial sector

\begin{tabular}{l|l} 
Excessive financial deepening & $\begin{array}{l}\text { Higher instability of the financial system } \\
\text { Higher incidence of financial crises } \\
\text { Inflation episodes } \\
\text { Weaker banking systems } \\
\text { Higher volatility of aggregate demand } \\
\text { Resources absorption by the financial sector (less resources to the real economy) } \\
\text { Weakening or reversal in the relationship between savings and investments }\end{array}$
\end{tabular}

Source: Authors' representation

Weakening or reversal in the relationship between savings and investments

Stockhammer (2010) also recognises that this excessive financial deepening was caused by a set of measures to deregulate the financial sector and to liberalise international capital flows. He agrees that some of these measures were a reaction to the increase of activities by private agents to circumvent financial regulations. This happened probably because the financial regulation was becoming ineffective. The same idea is shared by Orhangazi (2008a), who defends that the liberalisation of finance was accompanied by the emergence of financial innovations aimed at both circumventing financial regulations and responding to adverse macroeconomic conditions.

\section{THE CONCEPT AND THE EMERGENCE OF FINANCIALISATION}

In general terms, financial liberalisation and deregulation seem to have originated an excessive financial deepening with negative repercussions on the economic and social spheres. This negative relationship between the financial sector and the economic and social outcomes lead to the emergence of the concept of financialisation or finance-dominated capitalism ${ }^{3}$, translating the deleterious effects of financial deepening in the majority of world economies.

The origins of the concept of financialisation are not so clear, although it seems to have appeared in the early 1990s (Sawyer, 2013a; and Vercelli, 2013). Also, there is not a unique and generally accepted definition of financialisation (Krippner, 2004; and Leiva and Malinowitz, 2007). Note that "financialization is a short-hand expression for a number of developments over the last 30 years. The term is convenient but these developments may not have the coherence and unity suggested by the term and they may not signal the transition to some new 'regime" (Skott and Ryoo, 2008, p. 24). The same idea is shared by Dore (2008), who postulates that

3 These two expressions are normally used as interchangeably. Henceforth, we will only refer to the concept of financialisation.

DINÂMIA'CET - IUL, Centro de Estudos sobre a Mudança Socioeconómica e o Território ISCTE-IUL - Av. das Forças Armadas, 1649-026 Lisboa, PORTUGAL

Tel. 210464031 - Extensão 293100 E-mail: dinamia@iscte.pt http://dinamiacet.iscte-iul.pt/ 
Evolution of the financial sector - three different stages:

Repression, development and financialisation

“'financialisation' is a bit like 'globalization' - a convenient word for a bundle of more or less discrete structural changes in the economies of the industrialized world" (Dore, 2008, p. 1097).

Anyhow, one of the broadest concepts defines it as "[...] the increasing importance of financial markets, financial motives, financial institutions, and financial elites in the operations of the economy and its governing institutions, both at the national and international level" (Epstein, 2001, p. 1).

As recognised by Hein (2012), this is a broad and widely accepted definition of financialisation but lacks analytical precision. Sawyer (2013a) reiterates that this probably became the most widely cited definition of financialisation, albeit it underplays the influence of finance on society, does not specify the time period or geographical space to which it operates and does not provide any analytical framework for its study.

After presenting the aforementioned definition of financialisation, Epstein (2005b) adds the financialisation process exists in the most developed economies since the 1980s and has been characterized by the significant increase in financial transactions, the rise of real interest rates and higher profitability of financial corporations in relation to the non-financial corporations (NFCs).

Different authors tend to present other definitions of financialisation, emphasising other dimensions of that phenomenon. Lee et al. (2009) refer that it is possible to identify 17 concepts of financialisation on the literature and recognises that could be exist even more. French et al. (2011) alert that there is a danger that financialisation could become a "chaotic concept" or a "blanket term" that covers a range of related (but different) phenomena.

Despite this conceptual heterogeneity, all definitions of financialisation typically offer a negative perspective on the impact of excessive financial deepening in the real economy and in society. These concerns have gained momentum more recently in the wake of successive international financial crises (especially after the collapse of the US subprime crisis in 2007) and the resurgence of corporate scandals in the last two decades. Duménil and Lévy (2004) note that not all social classes are affected on the same degree by these types of crises or scandals. Some social classes are even favoured handsomely with finance benefits, whilst others (traditionally the general population) are strongly injured.

As a structural transformation of the economies, the financialisation process dates back to the 1970s or 1980s, in a context where occurred a strong transformation in the relationship between the financial sector and the real economy.

Kus (2012) notes that the financialisation process began in the US economy during the early 1980s, due to the adoption of a set of deregulatory reforms by Ronald Reagan

DINÂMIA'CET - IUL, Centro de Estudos sobre a Mudança Socioeconómica e o Território ISCTE-IUL - Av. das Forças Armadas, 1649-026 Lisboa, PORTUGAL 
Administration ("Reaganomics"), based on supply-side economics, liberal orientations and a laissez-faire philosophy.

Sawyer (2013a) reiterates that the dating of the financialisation process coincides with the emergence of an era of globalisation and neoliberalism during the administration of Ronald Reagan in the US and Margaret Thatcher in the United Kingdom (UK). This period was strongly marked by the growth in the volume of financial transactions, the liberalisation and deregulation of the financial sector and the emergence of securitisation.

Vercelli (2013) states that this process started before, in the 1970s, particularly with the end of Bretton Woods ${ }^{4}$ period in 1971, due to the beginning of a new era of deregulations undertaken by Richard Nixon's administration, which was characterized by the adoption of neoliberal policies and respective abandonment of Keynesian policies and full employment goals.

Tomaskovic-Devey et al. (2015) reiterates that this process occurs since the 1980s in the US with a substantial transformation from a "manufacture-driven" to a "finance-orientated" economy.

Freeman (2010) confirms that laissez-faire policies were endorsed by most economic leaders in the US and other advanced economies and by most of the international financial agencies (IMF, World Bank, among others), who were convinced by theory, ideology or by the influence of the leaders of financial institutions, which aimed to profit more in a less regulated financial environment.

These three phenomena - financialisation, globalisation and neoliberalism - appear to have evolved simultaneously during the last decades, and they seem to be dependent of each other. Orhangazi (2008a) recognises that globalisation and neoliberalism accompanied the evolution of financialisation. Fine (2011) stresses that globalisation and neoliberalism are both "elder siblings" of financialisation. He also adds that during the last thirty (or more) years neoliberalism has exacerbated the ideologies of non-intervention and efficacy of market forces, promoting the interests of private capital in general and of finance and financialisation in particular.

French et al. (2011) advice that it is clear that financialisation and neoliberalism are constituent of each other, albeit recognising that the order of their emergence and the direction of causality between them remain inconclusive. Lucarelli (2012) recognises that neoliberalism framed by financial deregulations, privatisations and greater labour market flexibility - provided

\footnotetext{
4 The Bretton Woods System was created after the $2^{\text {nd }}$ World War, according to which there were a strong international financial regulation based on fixed exchange rates and a dollar standard tied to the gold. 
the necessary conditions for the emergence of financialisation. Hein (2012) also stresses that financialisation is interrelated and overlaps with neoliberalism.

Vercelli (2013) reinforces that the timing of financialisation broadly overlaps with the timing of globalisation, recognising that the financialisation process may only occur with the reduction of spatial constraints to exchanges (e.g. removal of trade barriers) and that the process of globalisation was supported by internationalised finance. He also adds that the processes of financialisation and globalisation require a liberalisation of cross-country flows of goods, services and capital. Van der Zwan (2014) also states that globalisation and financialisation are not mutually exclusive analytical frameworks, but they are two sides of the same coin.

Despite the inexistence of a clear consensus related with the exact definition and the respective dating of the emergence of the financialisation process, the literature is unanimous to consider that the financialisation is not an isolated phenomenon that occurred independently of other economic and social transformations, instead was supported by the adoption of neoliberal policies and deregulatory reforms.

\section{FEATURES AND EFFECTS OF THE FINANCIALISATION PROCESS}

Against this background, Crotty (2005) highlights the existence of a "neoliberal paradox" in the financialisation process. He sustains that the demand of financial markets for more profits and higher stock prices could have an adverse effect on NFCs, because they responded to this pressure by cutting wages and benefits to workers, engaging in frauds and deceptions to increase apparent profits and moving into financial operations to increase profits, which ultimately delineates a stagnation of real economic growth in the medium and long-term.

This seems to illustrate the fragility and the unsustainable nature of the financialisation process and its negative impacts on the real economy and on social development. Some authors have even argued that the financialisation process has contributed to the subprime crisis in the US economy and to the Great Recession of 2008-2009 in Europe (e.g. Freeman, 2010; Stockhammer, 2010; Kedrosky and Stangler, 2011; and Hein, 2012). In fact, "after 2008 it became clear that financialization has the capacity to introduce instability into the US and other economies" (Tomaskovic-Devey et al., 2015, p. 1).

Menkhoff and Tolksdorf (2001) highlight the growing importance of stock markets, capital flows and international financial transactions as a demonstration of the financialisation process during the last three decades. Krippner (2005) looks to financialisation as the accumulation of profits from financial activities instead of other activities. Blackburn (2006) characterises financialisation as the increasing and systemic power of finance and financial

DINÂMIA'CET - IUL, Centro de Estudos sobre a Mudança Socioeconómica e o Território ISCTE-IUL - Av. das Forças Armadas, 1649-026 Lisboa, PORTUGAL 
engineering. Crotty (2007) argues that financialisation corresponds to a process where financial interests overlap the economic, social, environmental and political interests. Skott and Ryoo (2008) also argue that financialisation is associated with a number of international developments, such as the shift in monetary policy toward a near-exclusive focus on price stability, the increase of financial flows at both national and international levels, the improvement of financing conditions for households, the change in corporate governance through the alignment of managerial incentives with shareholder interests, and the increased influence and importance of financial institutions and institutional investors. Fine (2010) considers financialisation as the subjugation of economic activity to the logic and imperatives of capital. Stockhammer (2010) highlights that financialisation is used to refer the changes in the relation between the financial and the real sector, encompassing diverse phenomena, such as the emergence of "shareholder value orientation", increasing household debt, changes in behaviour of individuals (e.g. greater use of financial products), increasing incomes from financial activities by households and corporations, increasing frequency of financial crises and increasing international capital mobility. Vercelli (2013) postulates that financialisation designates a process characterised by an increasing weight and importance of finance or the financial side of economic decisions. Van der Zwan (2014) recognises that financialisation covers a host of empirical phenomenon at different levels of analysis, identifying it as a new regime of accumulation, the ascendancy of the "shareholder value orientation" and the encroachment of finance into the realms of everyday life.

Following Fine (2011), the FESSUD ${ }^{5}$ Description of Work (2011) recognises that financialisation is a complex term because it contains different dimensions and aspects. As exhibited in Figure 3, FESSUD (2011) discusses financialisation in terms of eight features, which have empirical support since the early 1980s (Sawyer, 2013a).

Figure 3 - Features of financialisation

\begin{tabular}{|c|c|}
\hline \multirow{7}{*}{$\begin{array}{l}\text { Features of } \\
\text { financialisation }\end{array}$} & Deregulation of \\
\hline & Emergence of new financial instruments, services, institutions and markets \\
\hline & $\begin{array}{l}\text { The dominance of finance over industry } \\
\text { The }\end{array}$ \\
\hline & \\
\hline & Rise of inequality deriving from market mechanisms and other public policies \\
\hline & Extension of credit that sustains the level of consumption \\
\hline & Penetration of market and financial logics in both economic and social spheres \\
\hline
\end{tabular}

Source: Authors' representation based on FESSUD (2011)

\footnotetext{
5 FESSUD is the acronym to "Financialisation, Economy, Society and Sustainable Development" Project, funded by the European Commission under Framework Programme 7 with a contract number 266800. The FESSUD Project aims to evaluate the changing on the role of the financial system during the last decades, involving the participation of some European partners, including Portugal through Centre for Social Studies - University of Coimbra and Dinâmia'CET-IUL. It is coordinated by a team from the University of Leeds in the UK and headed by Professor Malcolm Sawyer. For more information regarding the FESSUD project, please see http://fessud.eu/.
}

DINÂMIA'CET - IUL, Centro de Estudos sobre a Mudança Socioeconómica e o Território ISCTE-IUL - Av. das Forças Armadas, 1649-026 Lisboa, PORTUGAL 


\section{Evolution of the financial sector - three different stages: \\ Repression, development and financialisation}

Fine (2011) admits that these eight features were designed not only based on the US experience that he considers as the world's leading financial power, but also complemented with the experiences of the UK and other developed economies. Palley (2007) also recognises that financialisation seems to be more developed in the US economy. French et al. (2011) mention that the US and the UK are considered to be exemplar financialised economies.

However, Sawyer (2013a) adds that these features should be viewed as characteristics of the financialisation process in the Western industrialised economies, albeit recognising that the nature and speed of them varies between different countries. Vercelli (2013) agrees that the financialisation process has never been homogenous through time and space, since it is affected by cultural, material and political conditions that vary with time and place. Sawyer (2015) reiterates that the financialisation process is not uniform across countries and time.

In light of this, Power et al. (2003), Jayadev and Epstein (2007), Leiva and Malinowitz (2007), Palley (2007) and Orhangazi (2008a) also refer that financialisation is a common phenomenon across the majority of industrialised and developed economies, including many economies that lie outside the core of the world economy.

Notwithstanding, the theoretical and empirical research on financialisation has often been focused on the US, the UK and on economies of the centre, neglecting the specificities and dynamics of financialisation on the periphery (Becker et al., 2010 and French et al., 2011).

Yeldan (2000) concludes that the financialisation had a negative impact on economic growth, unemployment and income distribution in Turkey. He adds that finance has gained supremacy over other industries, which has proved to be harmful to the relationship between growth and productivity and to the intermediation process for real investments.

The same conclusion is obtained by Assa (2012), who confirmed that financialisation has definitely taken place in all countries of the Organisation for Economic and Co-operation and Development (OECD) with negative consequences on growth, employment and equality. He performs a panel data econometric analysis for the OECD countries, using the gross value added of financial activities and the employment of financial activities as proxies for financialisation. These two variables have a statistically significant and negative impact on economic growth, employment and personal income equality.

Leiva and Malinowitz (2007) suggest that financialisation has deteriorated the real economic performance of the North (developed) and South (developing) economies, namely delineating weak growth rates and lower levels of employment due to a decline of productive investments. Other consequences of that phenomenon include the deregulations of labourcapital relationship, the intensification of mergers and acquisitions to boost profits and

DINÂMIA'CET - IUL, Centro de Estudos sobre a Mudança Socioeconómica e o Território ISCTE-IUL - Av. das Forças Armadas, 1649-026 Lisboa, PORTUGAL 


\section{Evolution of the financial sector - three different stages: \\ Repression, development and financialisation}

shareholder value and, the reduction of the room of manoeuvre of public policies and the rise of inequality levels.

Becker et al. (2010) focus their analysis on the financialisation process in two countries from Latin America (Brazil and Chile) and other two from Eastern Europe (Serbia and Slovakia). He finds that this phenomenon has been extremely crisis-prone in all these four cases, also adding that the crisis faced by them has fostered the adoption of measures (promoted by the IMF or other international institutions) that feed the financialisation process, such as privatisations of pension systems in Chile and Slovakia. In this regard, Fine (2011) also claims that the policies promoted by the IMF or World Bank to minimise the severity of the crises in the past also stimulated the financialisation process, namely by reinforcing the open up of the economies to international financial capital.

Barradas et al. (2015) studies the emergence of financialisation in Portugal, finding that this phenomenon played an important role in creating the conditions that led to the recent sovereign debt crisis.

Indeed, as recognised by Sawyer (2013b and 2014), there is a dichotomy in the national financial systems around the world, based on the differences between a "bank-based (or dominated) financial system" and a "market-based (or dominated) financial system", that could be useful to explain the heterogeneous of the financialisation process over time and place. Nonetheless, both of them tend to be view in terms of the relationship between savings and investment.

According to Demirgüc-Kunt and Levine (2001), the "bank-based (or dominated) financial system" - presented in Germany and Japan - is characterised by the importance of banks on the mobilisation of savings, allocation of capital, supervision of the investment decisions of managers, and provision of risk management services. In the "market-based (or dominated) financial system" - presented in the US and in the UK - there is a higher preponderance of securities markets (vis-à-vis banks) in the intermediation process, corporate control and risk management.

Orsi and Solari (2010) also advance that the financial systems of Southern European economies are based on the first typology: banks control credit, the stock exchange and investment in shares, by acting as advisers, mediators, issuers, treasurers and investors. They sustain that, in those countries, banks are able to decide who can invest, where can invest, who makes profits and who loses.

Sawyer (2013b) presents a general critique to this dichotomy by considering that all financial systems require banks and almost all operate with stock markets and engage in market activities. Nonetheless, both types of financial systems have proved to be supporters of 


\section{Evolution of the financial sector - three different stages: \\ Repression, development and financialisation}

financialisation and give a weak support to investment (Sawyer, 2015). On the one hand, banks traditionally aim to maximise profits and therefore they tend to not allocate funds and loans to less profitable investments in the short-term but that are more socially desirable in the longterm. On the other hand, the stock market has demonstrated a limited role in the intermediation process, since the inflows of funds to corporations through equity markets are small and sometimes negatives.

Palley (2007) expresses that the financialisation process is often associated with a slower real economic growth. According to him, the financialisation process could imply a downward trend of real economic growth, increasing the importance of the financial sector in relation to the real sector, transferring income from the real sector to the financial sector and promoting income inequality and wage stagnation. This author still concludes that the financialisation process makes economies more vulnerable to debt-inflation episodes and prolonged recessionary environments.

Stockhammer (2010) also adverts that the financialisation process has been characterised by a sluggish overall economic performance with increasing financial fragility due to rising debt levels. Van der Zwan (2014) confirms that financialisation has increased the vulnerability of economies worldwide.

Sawyer (2013a) argues that has emerged much theoretical and empirical work regarding the deleterious effects of the financialisation process on economic and social performance. FESSUD (2011) summarises this claim through six general harmful effects, as demonstrated in Figure 4.

Figure 4 - General effects of financialisation

\begin{tabular}{c|l}
$\begin{array}{c}\text { Effects of } \\
\text { financialisation }\end{array}$ & $\begin{array}{l}\text { Reduction of the level and efficacy of real investments as funds diverted to financial activities } \\
\text { Prioritisation of shareholder value or financial worth in detriment of other values and goals }\end{array}$ \\
$\begin{array}{l}\text { Extension of market mechanisms to the economic and social public policies } \\
\text { Place more aspects of economic and social life at risk of volatility from financial instability } \\
\text { Encouragement of forms of culture and governance that affect the design of economic policies }\end{array}$
\end{tabular}

Source: Authors' representation based on FESSUD (2011)

More specifically, Stockhammer (2010) and Lapavitsas (2011) notes that the financialisation process has also had profound effects on the majority of economic agents: households, NFCs, financial corporations, and policy makers. Most of them arise from the aforementioned general effects of financialisation. They stress that households have become more financialised through a strong dependence of credit (especially for mortgage purposes), which has increased their debt levels and induced unsustainable levels of consumption (normally being considered irrational).

DINÂMIA'CET - IUL, Centro de Estudos sobre a Mudança Socioeconómica e o Território ISCTE-IUL - Av. das Forças Armadas, 1649-026 Lisboa, PORTUGAL 


\section{Evolution of the financial sector - three different stages: \\ Repression, development and financialisation}

Cynamon and Fazzari (2008), Zezza (2008), Barba and Pivetti (2009), Rajan (2010), Palley (2012), Stiglitz (2012) and van Treeck and Sturn (2012) provide extensive case studies around the increasing importance of wealth-based and debt-financed consumption on the US economy. Moreover, Guttmann and Plihon (2010) argue that consumption expenditures in the AngloSaxon countries have been essentially determined by changes in asset prices or in credit rather than by changes on income.

Stockhammer (2010) adds that the change in the provision of old-age retirement (from a State-provided social security based on a "pay-as-you-go" typology to an increase prominence of private and market-based provision of pensions based on "fully funded" typology), health insurance and the financing of education with credit are also other manifestations of households' financialisation. Palley (2007) argues that the provision of these services by the private sector feeds financial interests, because they generate large profits (from charges on custodial services and brokerage commissions), increase the demand for stocks that boost share prices and create an investor identity among households that favours policies supporting financial interests. Concurrently, Becker et al. (2010) recognise that the introduction of "fully funded" pension systems implies the forced integration of households into the realm of financial markets and a great push towards financialisation.

Against this background, Lapavitsas (2011) adds that households have become more financialised both as debtors (mortgages, general consumption, education, health, among others) and as asset holders (housing, pensions, insurance, money market funds, among others). Van der Zwan (2014) recognises that the financialisation of households also occurs in low-income and middle-class households, feeding the idea of 'popular finance'.

In relation to the non-financial corporate sector, Stockhammer (2010) emphasises that NFCs are more involved in financial activities, which soaks funds from real activities and hurts real investments. In addition, he stresses that "shareholder value orientation" of corporations has determined a rise of payout ratios of NFCs, which also restrains funds available for real investments.

On the other hand, Lapavitsas (2011) accepts that NFCs have reduced their reliance on bank loans, acquiring themselves financial capabilities. Baud and Durand (2012) also add that NFCs have also developed financial activities in their relationship with customers, by providing them with financial services (e.g. the development of consumption credit by retailers).

Against this backdrop, Krippner (2005) confirms that the US NFCs exhibit signs of financialisation since the 1970s, notably the growing importance of financial revenues (interest, dividends and capital gains from financial investments) in comparison with the revenues generated by productive activities and real investments.

DINÂMIA'CET - IUL, Centro de Estudos sobre a Mudança Socioeconómica e o Território ISCTE-IUL - Av. das Forças Armadas, 1649-026 Lisboa, PORTUGAL 


\section{Evolution of the financial sector - three different stages: \\ Repression, development and financialisation}

Regarding the financial sector, Stockhammer (2010) and Lucarelli (2012) admit that the financialisation process has been responsible for the emergence of a shadow banking system that is less regulated. This involved the appearance of certain institutions that do not take the form of traditional banking or insurance corporations, such as investment funds, money market funds, hedge funds, private equity funds, special purpose vehicles, among others.

Lapvitsas (2011) adds that in the era of financialisation banks have expanded their activities in financial markets to earn fees, commissions and profits from trading and they have directed the credit essentially to households. Concurrently, Lucarelli (2012) adds that commercial banks have begun to engage in financial market intermediation (as for instance, mediating mergers and acquisitions) and have expanded their operations into activities that were previously exclusively carried out by investment banks.

Palley (2007) adds that the financialisation process has also affected economic policies as a whole, promoting a policy framework based on globalisation (free trade, capital mobility, multi-national business and global sourcing), decline of government activity (privatisations, tax cuts on income and on capital that diminish public revenues and increase public deficit and public debt, deregulations and policies to introduce market mechanisms in the case of pensions and savings), abandonment of full employment goals (elevation of the importance of low inflation goal using inflation targeting policies and central bank independence), and labour market flexibility (decrease of trade unions power and erosion of labour market social supports, such as the minimum wage, employment benefits, employment protection and employees rights). He claims that this framework facilitated the expansion of financial markets and helped corporations to shift income from labour to capital, which feeds the interests of the financial sector.

These measures adopted by the policy makers have been responsible for a fall in wages and an increase of inequality levels. In this regard, Becker et al. (2010) advocate that the rise of inequality on income distribution accelerates by itself the financialisation process. This happens namely because the upper middle class earns higher wages that can be invested in the financial markets and the lower middle class are pressed to incur debts in order to maintain consumption standards and/or to acquire houses or other durable goods.

Figure 5 synthesises the main effects - appointed by the literature - of financialisation on households, NFCs, financial corporations and policy makers, respectively. 
Evolution of the financial sector - three different stages:

Repression, development and financialisation

\begin{tabular}{|c|c|c|}
\hline \multicolumn{3}{|c|}{ Figure 5 - Effects of financialisation on economic agents } \\
\hline & Households & $\begin{array}{l}\text { Strong dependence of credit } \\
\text { Strong indebtedness } \\
\text { Unsustainable levels of consumption } \\
\text { Holders of financial assets }\end{array}$ \\
\hline & Non-financial corporations & $\begin{array}{l}\text { Involvement in financial activities } \\
\text { Lower retention ratios } \\
\text { Provision of financial services }\end{array}$ \\
\hline Effects of financialisation & Financial corporations & $\begin{array}{l}\text { Increase of the shadow banking system } \\
\text { Direct credit to households } \\
\text { Commercial banks acting like investment banks }\end{array}$ \\
\hline & Policy makers & $\begin{array}{l}\text { Free trade } \\
\text { Privatisations } \\
\text { Tax cuts on income and on capital } \\
\text { Abandonment of full employment goals } \\
\text { Focus on inflation targeting policies } \\
\text { Labour market flexibility }\end{array}$ \\
\hline
\end{tabular}

Source: Authors' representation based on Palley (2007), Stockhammer (2010), Lapavitsas (2011), among others

Moreover and following a post Keynesian macroeconomic perspective, Hein and van Treeck (2010), Hein (2012) and Hein and Dodig (2015) highlight that the financialisation process has harmful effects on households' debt and consumption, real investment, income distribution, and on net exports and current account balances. Note that the majority of these macroeconomic effects are directly related with the aforementioned effects of the financialisation process on economic agents (i.e. they are the result of the effects of financialisation on economic agents).

Regarding consumption, it is argued that the financialisation process generated increasing potential for wealth-based and debt-financed consumption, which have increased financial fragility. On one hand, stock market valuations and housing price booms favoured a rise in notional wealth against which households were willing to borrow. On the other, a change in financial norms, the appearance of new financial instruments (like credit card debt and home equity loans) and the deterioration of creditworthiness standards triggered by securitisation strategies of commercial banks, favoured the availability of credit, even to low income and low wealth households. Obviously, these guaranteed a higher dynamism of private consumption, supporting economic growth.

Econometric studies have shown that financial wealth (fed by the financialisation process) exerts a statistically significant and a positive effect on private consumption (wealth effect on consumption), especially in those countries with a "market-based (or dominated) financial system", but also in countries with a "bank-based (or dominated) financial system". Some examples can be found in Boone et al. (1998), Ludvigson and Steindel (1999), Davis and 


\section{Evolution of the financial sector - three different stages: \\ Repression, development and financialisation}

Palumbo (2001), Ludwig and Sløk (2001), Mehra (2001), Edison and Sløk (2001), Boone and Girouard (2002), and Onaran et al. (2011).

In relation to real investment, it is stressed that the financialisation process exerts a negative impact on it due to the co-existence of a higher preference for financial investments by NFCs and strong pressures from the respective shareholders around the intensification of financial payments.

The increase of financial investments should at least guarantee a higher level of financial receipts, but they are used to fund further financial investments rather than to support real investments. The literature has presented several explanations to describe this higher engagement of NFCs in financial activities, such as the existence of shorter planning horizons (Samuel, 2000; Crotty, 2005; and Aspara et al., 2014), the trend to be more concerned with current profitability than with long-term expansion (Crotty, 1990; Orhangazi, 2008a and 2008b; Hein, 2012; and Hein and Dodig, 2015), the reduction of profits in the real sector and the increase in the external funding costs since the 1980s (Crotty, 2005; Orhangazi, 2008a and 2008b; Baud and Durand, 2012; Lin and Tomaskovic-Devey, 2013; and Soener, 2015), the macroeconomic uncertainty and the institutional changes at the level of corporate governance (Baud and Durand, 2012; Akkemik and Özen, 2014; and Soener, 2015), and the mimetic behaviour and the institutional transmission of knowledge and practices from other financialised NFCs and from financial executives and consultants (Soener, 2015).

The intensification of financial payments is associated with higher payout ratios, which constrain the funds available to finance real investments. The availability of funds has been even more reduced by the high levels of indebtedness of NFCs (Orhangazi, 2008a and 2008b), the existence of remuneration schemes based on the short-term evolution of stock prices (Orhangazi, 2008a and 2008b), the growing importance of institutional investors and the emergence of the paradigm of "shareholder value orientation" (Aglietta, 2000; Lazonick and O’Sullivan, 2000; Stockhammer, 2010; and van der Zwan, 2014).

Econometric evidence supporting the existence of a disruptive relationship between the financialisation process and real investment of NFCs can be found in Stockhammer (2004a), Orhangazi (2008a and 2008b), Van Treeck (2008), Onaran et al. (2011), Barradas and Lagoa (2014) and Barradas (2015). These empirical studies derive and estimate investment functions, finding evidence that financial receipts (from financial investments) and financial payments are both detrimental to the real investment of NFCs.

With regard to income distribution, it is claimed that the financialisation process increased the inequality of both personal and functional income distribution, visible in the growing trend of top management salaries, in the fall of the labour income share, and in the rise

DINÂMIA'CET - IUL, Centro de Estudos sobre a Mudança Socioeconómica e o Território ISCTE-IUL - Av. das Forças Armadas, 1649-026 Lisboa, PORTUGAL 


\section{Evolution of the financial sector - three different stages: \\ Repression, development and financialisation}

of the profit share. The major reasons appointed for these trends have been the change in sectorial composition of the economy in favour of the financial sector, the "shareholder value orientation" of NFCs and the fall in the bargaining power of trade unions.

From an empirical view point, Assa (2012), Kus (2012), Czaplicki and Wieprzowski (2013) and Karanassou and Sala (2013) analyse econometrically the relationship between the financialisation process and personal income distribution. These studies use the traditional measure of Gini coefficient as dependent variable, concluding that the financialisation process had a significant negative impact on equality levels.

Stockhammer (2009), Kristal (2010), Peralta and Escalonilla (2011), Dünhaupt (2013a), Lin and Tomaskovic-Devey (2013) and Barradas and Lagoa (2015) address empirically the relationship between the financialisation process and functional income distribution. The majority of these studies derive and estimate a labour income share, finding evidence supporting the claim that the financialisation process had a statistically significant and negative impact on the labour income share.

Regarding current account balances, it is argued that the financialisation process has created problems of foreign indebtedness, speculative capital flows, exchange rate volatiles, currency crises and persistent current account deficits. At the same time, the liberalisation of international capital markets and capital accounts has allowed for rising current imbalances at the global and regional levels, in particular within the euro area (EA) (Hein, 2012).

Figure 6 offers a general overview regarding the main macroeconomic effects linked with the financialisation process.

Figure 6 - Macroeconomic effects of financialisation

\begin{tabular}{|c|c|c|}
\hline & Private consumption & $\begin{array}{l}\text { Debt-financed consumption } \\
\text { Rise in notional wealth } \\
\text { Higher availability of credit }\end{array}$ \\
\hline & Real investment & $\begin{array}{l}\text { Involvement in financial activities } \\
\text { Lower retention ratios }\end{array}$ \\
\hline $\begin{array}{c}\text { Effects of } \\
\text { financialisation }\end{array}$ & $\begin{array}{c}\text { Income distribution } \\
\text { (personal and functional) }\end{array}$ & $\begin{array}{l}\text { Rise in top management salaries } \\
\text { Decline of labour income share and increase of profit share }\end{array}$ \\
\hline & Current account & $\begin{array}{l}\text { Foreign indebtedness } \\
\text { Speculative capital flows } \\
\text { Exchange rate volatile } \\
\text { Currency crises } \\
\text { Persistent current account deficits }\end{array}$ \\
\hline
\end{tabular}

Source: Authors' representation based on Hein and van Treeck (2010), Hein (2012) and Hein and Dodig (2015) 


\section{Evolution of the financial sector - three different stages: \\ Repression, development and financialisation}

Stockhammer (2010) stresses that the financialisation process has given rise to two different growth models: a "consumption-driven growth model" and an "exported-oriented growth model". Hein (2012) refers them as two types of capitalism under financialisation: the "debt-led consumption boom" and "export-led mercantilist" models, respectively.

The first growth model - mostly presented in Anglo-Saxon countries, US, UK and Ireland, but also in Greece and Spain, since the end of 1990s - is associated with a strong growth of credit and increasing levels of indebtedness. Dodig et al. (2015) add that this growth model is also present in Estonia and in South Africa. In all of these countries, a property boom allowed households to increase mortgage loans that they could not afford given their income, but that seemed reasonable to banks which assumed that housing prices would continue to increase. The effect of the property boom can be interpreted by the financial accelerator theory developed by Bernanke et al. (1996), which stresses that asset price inflation tends to raise collateral values, which allows more borrowing to finance consumption and investment.

Effectively, the majority of these countries developed a "credit-financed consumption boom" that boosted a fairly vigorous economic growth supported by private consumption and domestic demand. Households of these countries exhibit negative financial balances, which also translate into negative balances of the private sector (households and corporations) as a whole, despite the positive financial balances of the corporate sector. Public sector contributes to a negative domestic financial balance. These countries have persistent deficits on the balance of goods and services and on the current account balance, since aggregate domestic expenditures supplanted national income.

Hein (2012) also adds that for the EA countries these deficits were also caused by an increase of unit labour costs and inflation accompanied by nominal appreciation of the euro, which caused a loss of competitiveness of domestic producers. For that reason, financial balances of the external sector have remained positive.

The second growth model - more useful to characterise Austria, Belgium, Germany, the Netherlands, Sweden, Japan and China since the end of 1980s - is related with the strong importance of net exports in aggregated demand, in a context where consumption and investment remained weak. These countries have experienced impressive surplus on the balance of goods and services and on the current account balance that have been partly used to finance credit bubbles of the first group of countries. In fact, these countries benefited from world demand driven by the "debt-led consumption boom" economies. So, in these countries, financial balances of the external sector are negatives. The financial balances of households and corporate sectors are positive, whereas public sector has negative financial balances. Hein (2012) adds that these surpluses are supported by a weak domestic demand, low unit labour cost growth, low inflation and a nominal depreciation of the currency in the case of Japan.

DINÂMIA'CET - IUL, Centro de Estudos sobre a Mudança Socioeconómica e o Território ISCTE-IUL - Av. das Forças Armadas, 1649-026 Lisboa, PORTUGAL 
Both growth models are susceptible to slowdown, like what happened after the collapse of the US subprime crisis in 2007. In fact, any recession in the "debt-led consumption boom" economies causes a deceleration of "export-led mercantilist" economies because they are strongly dependent of the world demand and of their export markets.

Nonetheless, Hein (2012) also claims that some countries do not fit into any of the aforementioned two types of models. As for instance, he notes that France, Italy and Portugal can neither be considered to have been "debt-led consumption boom" economies nor "export-led mercantilist" economies since the end of 1990s. This happens because these countries exhibit positive financial balances of households and negative financial balances of public and corporate sectors, in a context where aggregate demand was driven essentially by domestic demand. These countries could be labelled as a third growth model in the era of financialisation: the "domestic demand-led". External sector has positive financial balances in France and Portugal, but negative financial balances in Italy. Dodig et al. (2015) add that Hungary, Poland and Turkey, have also a "domestic demand-led" growth model. According to these authors, Hungary, Poland and Turkey are considered "catching-up domestic demand-led countries", whereas France, Italy and Portugal are considered "mature domestic demandled countries". This difference is related with higher growth rates of the first group of countries, probably because they have their own currencies and lower levels of GDP per capita.

Figure 7 contains the main characteristics associated with the aforementioned growth models in the era of financialisation.

Figure 7 - Growth models or types of capitalism under financialisation and the respective characteristics

Growth models or types of capitalism

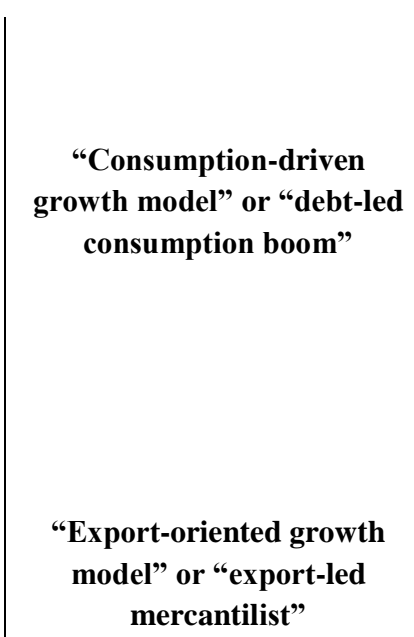

mercantilist"

\author{
Growth supported by consumption \\ Strong growth of credit \\ Higher levels of indebtedness \\ Property boom \\ Deficits on external balances \\ Households with negative financial balances \\ Corporations with positive financial balances \\ Public sector with negative financial balances \\ External sector with positive financial balances \\ Growth supported by net exports \\ Sluggish domestic demand \\ Surplus on external balances \\ Households with positive financial balances \\ Corporations with positive financial balances \\ Public sector with negative financial balances \\ External sector with negative financial balances
}
"Domestic demand-led" (catching-up and mature economies)

Source: Authors' representation based on Stockhammer (2010) and Hein (2012) 
Evolution of the financial sector - three different stages:

Repression, development and financialisation

\section{POLICY IMPLICATIONS AND THE NEED TO DE- FINANCIALISATION}

The literature on financialisation suggests that could be necessary a reversal in the importance and in the power of the financial sector in the coming years, in order to re-achieve a higher sustainability of the financial system and re-establish a more supportive relationship between the financial sector and the real economy by reinforcing the efficiency of the link between savings and investment.

The argument is that the expressive growth of the financial sector in the last decades has not been associated with a faster economic growth, but instead with slower growth, higher levels of unemployment, rising inequality and increased incidence of financial and economic crisis. This suggests the need to engage in policies that could be more conductive to economic growth, employment, quality of jobs, equality, and human development, which requires a higher sustainability of the financial system. In general, there is the need to take on in a definancialisation process in the near future.

In fact and as noted by Palley (2007), "financial markets are at the heart of the financialization process, and that suggests there is an urgent to restore effective control over these markets" (Palley, 2007, p. 22). In the same fashion, Vercelli (2013) claims that "the word and the underlying concept [of financialisation] started to be adopted widely in the following years but almost exclusively by heterodox economists who differently from orthodox ones, see financialization as a serious problem to be understood and removed, or at least mitigated" (Vercelli, 2013, p. 20). He still adds that "[...] the process of financialisation is mainly a pathological process of evolution within capitalism that requires that capitalism be radically reformed or superseded" (Vercelli, 2013, p. 41).

In order to fulfil this purpose, Palley (2007) enumerates a set of policy recommendations related with three different dimensions, namely the neoliberalism philosophy, the corporate governance model and economic policy as a whole.

In relation to the neoliberalism framework, he suggests the need to replace the current globalisation of corporations by a globalisation that may favour an equitable development, to substitute the decrease of government activity by a better government activity and to replace labour market flexibility by better jobs and productive workplaces.

Regarding the corporate governance model, the author argues the need to reduce the excessive payments to managers and shareholders, fight the lack of corporate accountability and the existence of misaligned incentives within corporations that favour the interests of shareholders rather than the ones of stakeholders (like employees). Against this backdrop, Dünhaupt (2013b) suggests that is crucial to replace the short-term focus imposed on

DINÂMIA'CET - IUL, Centro de Estudos sobre a Mudança Socioeconómica e o Território ISCTE-IUL - Av. das Forças Armadas, 1649-026 Lisboa, PORTUGAL 
corporations by the "shareholder value orientation" by a system of corporate governance that involves all stakeholders. She adds that this should be put in place by the adoption of tax policies and/or the imposition of competition laws in order to reduce monopoly profits.

With regard to the economic policy, he proposes the need to tackle issues around lobbying and the influence of wealth on politics. He also suggests the need to adopt a monetary policy framework that can help to stabilise the international financial markets and do not harm the real economy. He notes that the majority of international central banks have the short-term interest rate as the only effective policy instrument, which proved to be insufficient to circumvent the trade-off between curtailing financial speculation (by raising interest rates) and sustaining economic growth (by decreasing interest rates). Against this backdrop, he proposes that the central banks should adopt a regulatory framework based on Asset-Based Reserve Requirements (ABRR), which imposes that all financial institutions (and not just banks) are obliged to hold reserves for all types of assets and not only for their deposits liabilities ${ }^{6}$.

Concurrently, Hein (2012) advocates a strategy imbedded in a Global Keynesian New Deal, in order to circumvent the deleterious effects of the financialisation process paved in the last decades that contributed to the severity of the recent financial and economic crisis of the Great Recession. In general terms, this strategy is constructed in three different pillars ${ }^{7}$, namely the re-regulation of the financial sector in order to prevent future crises, the re-orientation of macroeconomic policies in order to stimulate and stabilise domestic demand and to improve employment levels, and the re-construction of an international macroeconomic policy coordination and a new world financial order. For each pillar, the author suggests a set of specific policy measures.

Regarding the re-regulation of the financial sector, he stresses the need to reduce the problems of uncertainty, asymmetric information, moral hazard and fraud; to focus on longterm growth rather than short-term profitability; and to contain systemic financial instability. Accordingly, he proposes the implementation of the following measures: the standardisation, supervision and regulation at a national and international level of all financial products and nonbank financial institutions (insurance corporations, hedge funds, private equity funds, among others); the abolishment of off-balance sheet operations; the creation of independent public rating agencies in order to replace the private ones; the diversification of the banking system through the creation of public and co-operative banks in order to increase the supply of credit to

\footnotetext{
6 Palley (2004) and Hein (2012) present the general terms of a system based on ABRR, as well as its microeconomic and macroeconomic advantages.

7 Hein (2012) claims that these three pillars are related to what he considers the three main causes of the Great Recession, namely the inefficient regulation of the financial system, the increasing inequality in the income distribution and the growing imbalances at the global and at the EA level.
} 
small and medium corporations; the reinforcement of the financial intermediation function of banks; the reduction of securitisation operations in order to prevent the strategies of "originate to distribute" with high systemic risks; the reduction or even abolishment of share buybacks strategies by corporations; the minimisation of short-termism behaviour of managers in order to boost the realisation of long-term projects; the improvement of equity requirements in order to reduce leverage and to make financial intermediaries more resilient; the separation of commercial banks (savings and loans) from investment banks and from the shadow banking system in order to prevent contagion in the case of crises in the two last types of organizations; the introduction of ABRR; and the creation of a general transaction tax for all financial transactions and a general capital gains tax in order to reduce speculation and volatility of shortterm financial flows. According to him, these measures, if implemented, will contribute to stabilise and orientate the financial sector to finance real activity and therefore favouring a higher dynamism of the aggregate demand ${ }^{8}$.

With regard to the re-orientation of macroeconomic policies, he proposes three set of measures oriented to the role of international central banks, the design of fiscal policies and the framework around incomes and wage policies. Thus, he argues that central banks should target low real interest rates in order to avoid unfavourable cost and distribution effects on corporations and workers", should act as "lender of last resort" mainly in period of liquidity crisis and should be involved in the regulation and supervision of the financial markets through the definition of credit standards for refinancing operations with commercial banks, the implementation of compulsory reserve requirements for different financial assets and the establishment of credit controls. He also claims that fiscal policies should be designed in order to guarantee a real stabilisation of the business cycle, full employment and a more equal distribution of disposable income, namely through the rise of public investment in infrastructures or in education and the implementation of progressive income taxes; relevant wealth, property and inheritance taxes; and social transfers in favour of low income and low wealth households. Finally, he stresses the importance of a higher wage bargaining coordination and organised labour markets through the reinforcement of trade unions and/or other

\footnotetext{
8 Hein (2012) also reinforces that the implementation of these measures will contribute to mitigate inequalities on income distribution, through three different channels. First, these measures imply a decrease of the financial sector, which contribute to contain the fall in the labour income share. Second, these measures boost the reduction of top management salaries and profit claims of financial wealth holders, which also contribute to mitigate the decline of the labour income share. Third, these measures intensify the orientation of managers to long-term expansion, which will favour a rise of the bargaining power of workers and trade unions and therefore an increase of the labour income share.

${ }^{9}$ Hein (2012) suggests a target of a slightly positive real interest rate, below the long-term rate of productivity growth.
}

DINÂMIA'CET - IUL, Centro de Estudos sobre a Mudança Socioeconómica e o Território ISCTE-IUL - Av. das Forças Armadas, 1649-026 Lisboa, PORTUGAL 


\section{Evolution of the financial sector - three different stages: \\ Repression, development and financialisation}

employer associations and the need to establish a legal minimum legislation that contain wage dispersion in order to contribute to a higher equality in income distribution.

In relation to the re-construction of an international macroeconomic policy coordination and a new world financial order, he suggests increases in international policy coordination, namely through the establishment of targets for current account balances, the return to a cooperative world financial order, the adoption of a system with fixed but adjustable exchange rates and the implementation of international regulation of capital flows.

Vercelli (2013) claims that the best strategy is the implementation of a policy strategy that could filter the positive effects from the negative effects of the growth of the financial sector. He sustains that this may be done through the limitation of banks' freedom of acting and the excessive speculation, as for instance by imposing a Tobin tax on financial transactions. Sawyer (2015) also suggests the creation of financial transaction taxes or financial activity taxes, since the substantial growth of trading in the form of financial assets did not generate economic growth and employment. Accordingly, the aim of these taxes is the reduction of the volume of financial transactions and the release of resources (which are engaged in those transactions) to the most productive directions.

Sawyer (2015) centres its attentions and recommendations in the need to develop, support and promote other financial institutions focused on the links between savings and investment. He emphasises that there are a wide range of financial institutions with different forms of ownership (private, public and mutual and co-operative), different objectives and market segments, but only some of them have been compatible with social and environmental objectives. So, he proposes the emergence of alternative forms of financial institutions, namely microfinance institutions, State development and investment banks, ethical banking and the mutual and local financial institutions. These new financial institutions should be able to finance more socially-oriented projects rather than to focus exclusively on profits and they should be organised at local and regional levels. Concurrently, he defends the adoption of credit allocation policies in order to channel more funds to productive economic activities. These credit allocation policies should include the introduction of interest rates subsidies, loans guarantee programs and tax incentives.

In this regard, international policy makers should take into account the aforementioned policy recommendations in order to contain a deepening of the financialisation process and mitigate its harmful effects in the coming years. However, it should be recognised that policy makers at the national level have little margin of manoeuvre to implement the majority of these measures in the short-term, which is due to three fundamental reasons. Firstly, some of these measures imply international coordination, and these policy makers do not have the sufficient power to persuade

DINÂMIA'CET - IUL, Centro de Estudos sobre a Mudança Socioeconómica e o Território ISCTE-IUL - Av. das Forças Armadas, 1649-026 Lisboa, PORTUGAL 


\section{Evolution of the financial sector - three different stages: \\ Repression, development and financialisation}

its international partners for its adoption. Secondly, these policy makers are constantly pressed to sustain a fiscal consolidation, which prevent them to adopt some of these recommendations that could delineate an increase of the respective public deficit and public debt. This is particularly relevant in the case of EA. Thirdly and in the case of small economies of the EA, the respective policy makers do not have the better conditions in terms of political importance to negotiate a substantial change of the design of the respective monetary policy and deep changes in the rules of banking regulation with the European Central Bank.

Against this background, van der Zwan (2014) notes that in the recent years emerged new initiatives that aim to reduce the power of finance, namely inside the realm of finance (through the appearance of peer-to-peer lending platforms and the reinforcement of cooperative banks) and outside (via the resurgence of new forms of community ownership and systems of sharing). Nonetheless, she emphasises that these measures have been insufficient (due to their small scale), probably because there has not been a change in economic thinking, like what happened with the implementation of New Deal in the 1930s. This represents a strong constrain to policy makers (and academics) to present new economic strategies that could induce a higher long-term sustainability, inclusiveness and equality.

Anyhow, these constrains should not serve as an excuse to do nothing, since some measures are compatible with these forces. Policy makers of each economy should try to find the best way to make these constrains compatible with the need to engage in a definancialisation process. This is the real challenge for the coming years! 


\section{CONCLUSION}

This paper presented a systematic literature review on the evolution of the financial sector all around the world in the last decades. This evolution comprises three different stages (financial repression, financial development, and financialisation), reflecting distinct impacts of the financial sector in the real economy or in general society.

Effectively and for many years, the financial sector was subject to high levels of regulations and restrictions, which seemed to constrain economic growth. This period was characterized by a certain level of financial repression all over the world.

However, in the last decades and especially after the beginning of 1980 s, there was a strong liberalisation and deregulation of the financial sector, which occurred due to two fundamental reasons. Conventional economic theory, supported by empirical studies, postulated that the financial development would be crucial to ensure a higher economic growth given its positive effect on savings and investment.

The liberalisation and deregulation of the financial sector resulted in a huge growth of the financial system, not only in terms of deposits, loans and stock market valuations, but also of other areas related with derivatives, securitisation and shadow banking. This originated an excessive financial deepening, increasing doubts on the "finance-growth nexus" and feeding fears around the unsustainable nature of this new deregulated framework.

In general terms, the concept of financialisation corresponds to the negative effects arising from this excessive financial deepening on the real economy, on economic agents and on macroeconomic outcomes. This is a broad concept that encompasses several dimensions, albeit all of them offer a negative view of the growth of finance.

This suggests the need to take on in a fourth stage (de-financialisation), in order to reverse the current disruptive relationship between the financial sector and the real economy. The literature presents several recommendations that should be adopted by policy makers in the near future, which should promote a higher sustainability of the financial system, making it more conductive to economic growth, employment, quality of jobs, equality, and human development.

DINÂMIA'CET - IUL, Centro de Estudos sobre a Mudança Socioeconómica e o Território ISCTE-IUL - Av. das Forças Armadas, 1649-026 Lisboa, PORTUGAL 


\section{REFERENCES}

AGHION, P., HOWITT, P. and MAYER-FOULKES, D., 2005. The Effect of Financial Development on Convergence: Theory and Evidence. Quarterly Journal of Economics, 120(1), $173-222$

AGLIETTA, M., 2000. Shareholder value and corporate governance: some tricky questions. Economy and Society, 29(1), 146-159.

AKKEMIK, K.A. and ÖZEN, Ş., 2014. Macroeconomic and institutional determinants of financialisation of non-financial firms: Case study of Turkey. Socio-Economic Review, 12(1), 71-98.

ANG, J.B., 2008. A Survey of Recent Developments in the Literature of Finance and Growth. Journal of Economic Surveys, 22(3), 536-576.

ARESTIS, P., ChORTAREAS, G., and MAGKONIS, G., 2015. The Financial Development and Growth Nexus: A Meta-Analysis. Journal of Economic Surveys, 29(3), 549-565.

ARROW, K.J. and DEBREU, G., 1954. Existence of an Equilibrium for a Competitive Economy. Econometrica, 22 (3), 265-290.

ASPARA, J., PAJUNEN, K., TIKKANEN, H., and TAINIO, R., 2014. Explaining corporate short-termism: self-reinforcing processes and biases among investors, the media and corporate managers. Socio-Economic Review, 12(4), 667-693.

ASSA, J., 2012. Financialisation and its Consequences: the OECD Experience. Finance Research, 1(1), 35-39.

BARAJAS, A., BECK, T., DABLA-NORRIS, E. and YOUSEFI, S.R., 2013. Too Cold, Too Hot, or Just Right? Assessing Financial Development Across the Globe. IMF Working Paper N. ${ }^{\circ}$ 13/81. Washington: International Monetary Fund.

DINÂMIA'CET - IUL, Centro de Estudos sobre a Mudança Socioeconómica e o Território ISCTE-IUL - Av. das Forças Armadas, 1649-026 Lisboa, PORTUGAL 
Evolution of the financial sector - three different stages:

Repression, development and financialisation

BARAJAS, A., CHAMI, R. and YOUSEFI, S.R., 2012. The Finance and Growth Nexus ReExamined: Do All Countries Benefit Equally? IMF Working Paper, N. ${ }^{\circ}$ 13/130. Washington: International Monetary Fund.

BARBA, A. and PIVETTI, M., 2009. Rising household debt: Its causes and macroeconomic implications - a long period analysis. Cambridge Journal of Economics, 33(1), 113-137.

BARRADAS, R., 2015. Financialisation and real investment in European Union: beneficial or prejudicial effects?. Mimeo. Lisboa: ISCTE-IUL, Department of Political Economy.

BARRADAS, R. and LAGOA, S., 2014. Financialisation and the Portuguese real investment: a supportive or a disruptive relationship?. Dinâmia'CET-IUL Working Paper, N. ${ }^{\circ}$ 06. Lisboa: ISCTE-IUL.

BARRADAS, R. and LAGOA, S., 2015. Functional income distribution in a small European country: the role of financialisation and other determinants. Mimeo. Lisboa: ISCTE-IUL, Department of Political Economy.

BARRADAS, R., LAGOA, S., LEÃO, E. and MAMEDE, R.P., 2015. Financialisation in the European Periphery and the Sovereign Debt Crisis: The Portuguese Case. Mimeo. Lisboa: ISCTE-IUL, Department of Political Economy.

BAUD, C. and DURAND, C., 2012. Financialization, globalization and the making of profits by leading retailers. Socio-Economic Review, 10(2), 241-266.

BECK, T., DEGRYSE, H. and KNEER, C., 2014. Is more finance better? Disentangling intermediation and size effects of financial systems. Journal of Financial Stability, 10(1), 50-64.

BECKER, J., JÄGER, J., LEUBOLT, B. and WEISSENBACHER, R., 2010. Peripheral Financialisation and Vulnerability to Crisis: A Regulationist Perspective. Competition and Change, 14(3-4), 225-247.

BERNANKE, B., GERTLER, M. and GILCHRIST, S., 1996. The Financial Accelerator and the Flight to Quality. The Review of Economics and Statistics, 78(1), 1-15.

DINÂMIA'CET - IUL, Centro de Estudos sobre a Mudança Socioeconómica e o Território ISCTE-IUL - Av. das Forças Armadas, 1649-026 Lisboa, PORTUGAL 
Evolution of the financial sector - three different stages:

Repression, development and financialisation

BLACKBURN, R., 2006. Finance and The Fourth Dimension. New Left Review, 39, 39-70.

BOONE, L. and GIROUARD, N., 2002. The Stock Market, the Housing Market and Consumer Behaviour. OECD Economic Studies, 35, 175-200.

BOONE, L., GIORNO, C. and RICHARDSON, P., 1998. Stock Market Fluctuations and Consumption behaviour - Some Recent Evidence. OECD Economics Department Working Paper, N. ${ }^{\circ} 208$.

CECCHETTI, S.G. and KHARROUBI, E., 2012. Reassessing the impact of finance on growth. BIS Working Papers, N. ${ }^{\circ} 381$.

CROTTY, J.R., 1990. Owner-manager conflict and financial theory of investment stability: a critical assessment of Keynes, Tobin, and Minsky. Journal of Post Keynesian Economics, 12(4), 519-542.

CROTTY, J.R., 2005. The Neoliberal Paradox: The Impact of Destructive Product Market Competition and Impatient Finance on Nonfinancial Corporations in the Neoliberal Era. IN: EPSTEIN, G.A. ed. Financialisation and the World Economy, Cheltenham: Edward Elgar Publishing Limited.

CROTTY, J.R., 2007. If Financial Market Competition is so Intense, Why are Financial Firms Profits so High? Reflections on the Current 'Golden Age' of Finance. PERI Working Paper, N. ${ }^{\circ}$ 134. Washington: Political Economy Research Institute.

CYNAMON, B.Z. and FAZZARI, S.M., 2008. Household Debt in the Consumer Age: Source of Growth - Risk of Collapse. Capitalism and Society, 3(2), 1-30.

CZAPLICKI, M. and WIEPRZOWSKI, P., 2013. The Impact of Financialisation on Income Inequality. Mimeo. Warsaw: Warsaw School of Economics, Collegium of Social and Economic Science.

DABLA-NORRIS, E. and SRIVISAL, N., 2013. Revisiting the Link Between Finance and Macroeconomic Volatility. IMF Working Paper, N. ${ }^{\circ}$ 13/29. Washington: International Monetary Fund.

DINÂMIA'CET - IUL, Centro de Estudos sobre a Mudança Socioeconómica e o Território ISCTE-IUL - Av. das Forças Armadas, 1649-026 Lisboa, PORTUGAL 
Evolution of the financial sector - three different stages:

Repression, development and financialisation

DAVIS, G.F., 2009. Managed by the Markets: How Finance Re-Shaped America. Oxford: Oxford University Press.

DAVIS, M.A. and PALUMBO, M.G., 2001. A Primer on the Economics and Time Series Econometrics of Wealth Effects. Finance and Economics Discussion Series, N. ${ }^{\circ}$ 9. Washington: Federal Reserve Board.

DEMIR, F., 2009. Financial Liberalization, Private Investment and Portfolio Choice: Financialisation of Real Sectors in Emerging Markets. Journal of Development Economics, 88(2), 314-324.

DEMIRGÜC-KUNT, A. and LEVINE, R., 2001. Financial Structure and Economic Growth: A Cross-Country Comparison of Banks, Markets, and Development. Cambridge: MIT Press.

DODIG, N., HEIN, E. and DETZER, D., 2015. Financialisation and the financial and economic crises: Theoretical framework and empirical analysis for 15 countries. FESSUD Working Paper Series, N. ${ }^{\circ} 110$. Leeds: University of Leeds.

DORE, R., 2008. Financialization of the global economy. Industrial and Corporate Change, 17(6), 1097-1112.

DUMÉNIL, G. and LÉVY, D., 2004. Capital Resurgent: Roots of the Neoliberal Revolution. New York: Harvard University Press.

DÜNHAUPT, P., 2013a. The effect of financialisation on labor's share of income. IPE Working Paper, N. ${ }^{\circ}$ 17/2013. Berlin: Institute for International Political Economy.

DÜNHAUPT, P., 2013b. Determinants of functional income distribution - Theory and empirical evidence. GLU Working Paper, N. ${ }^{\circ} 18$. Berlin: Global Labour University.

EDISON, H. and SLØK, T., 2001. Wealth Effects and the New Economy. IMF Working Paper, N. ${ }^{\circ}$ 01/77. Washington: International Monetary Fund.

EPSTEIN, G.A., 2001. Financialisation, Rentier Interests and Central Bank Policy. Mimeo. Amherst: University of Massachusetts, Department of Economics.

DINÂMIA'CET - IUL, Centro de Estudos sobre a Mudança Socioeconómica e o Território ISCTE-IUL - Av. das Forças Armadas, 1649-026 Lisboa, PORTUGAL Tel. 210464031 - Extensão 293100 E-mail: dinamia@iscte.pt http://dinamiacet.iscte-iul.pt/ 
Evolution of the financial sector - three different stages:

Repression, development and financialisation

EPSTEIN, G.A., 2005a. Central Banks as Agents of Economic Development. PERI Working

Paper, N. ${ }^{\circ}$ 104. Washington: Political Economy Research Institute.

EPSTEIN, G.A., 2005b. Financialisation and the World Economy. Cheltenham: Edward Elgar Publishing Limited.

FESSUD, 2011. Description of Work. IN: FESSUD, Grant Agreement N. 266800 for Collaborative Project Under Framework Programme 7 of the European Union, Leeds: University of Leeds.

FINE, B., 2010. Locating Financialisation. Historical Materialism, 18(2), 97-116.

FINE, B., 2011. Financialisation on the Rebound. Mimeo. London: SOAS University of London.

FREEMAN, R.B., 2010. It's financialization!. International Labour Review, 149(2), 163-183.

FRENCH, S., LEYSHON, A. and WAINWRIGHT, T., 2011. Financializing space, spacing financialization. Progress in Human Geography, 35(6), 798-819.

FRIEDMAN, M., 1953. Essays in Positive Economics. Chicago: Chicago University Press.

GUTTMANN, R. and PLIHON, D., 2010. Consumer debt and financial fragility. International Review of Applied Economics, 24(3), 269-283.

HEIN, E., 2009. A (Post-)Keynesian perspective on 'financialisation'. IMK Study, N. ${ }^{\circ}$ 1/2009. Düsseldorf: Macroeconomic Policy Institute.

HEIN, E., 2012. The Macroeconomics of Finance-dominated Capitalism - and its Crisis. Cheltenham: Edward Elgar Publishing Limited.

HEIN, E. and DODIG, N., 2015. Finance dominated capitalism, distribution, growth and crisis long-run tendencies. IN: HEIN, E., DETZER, D. and DODIG, N., eds. The Demise of Financedominated Capitalism: Explaining the Financial and Economic Crises, Cheltenham: Edward Elgar Publishing Limited, pp. 54-114.

DINÂMIA'CET - IUL, Centro de Estudos sobre a Mudança Socioeconómica e o Território ISCTE-IUL - Av. das Forças Armadas, 1649-026 Lisboa, PORTUGAL Tel. 210464031 - Extensão 293100 E-mail: dinamia@iscte.pt http://dinamiacet.iscte-iul.pt/ 
Evolution of the financial sector - three different stages:

Repression, development and financialisation

HEIN, E. and VAN TREECK, T., 2010. 'Financialisation' in Post-Keynesian Models of Distribution and Growth: A Systematic Review. IN: SETTERFIELD, M., ed. Handbook of Alternative Theories of Economic Growth, Cheltenham: Edward Elgar Publishing Limited, pp. 277-292.

INTERNATIONAL MONETARY FUND, 2006. Global Financial Stability Report: Market Developments and Issues. Washington.

JAYADEV, A. and EPSTEIN, G., 2007. The Correlates of Rentier Returns in OECD Countries. PERI Working Paper, N. ${ }^{\circ}$ 123. Washington: Political Economy Research Institute.

JENSEN, M.J. and MECKLING, W.H., 1976. Theory of the Firm: Managerial Behavior, Agency Costs and Ownership Structure. Journal of Financial Economics, 3(4), 305-360.

KARANASSOU, M. and SALA, H., 2013. Distributional Consequences of Capital Accumulation, Globalisation and Financialisation in the US. IZA Discussion Paper, N. ${ }^{\circ} 7244$. Bonn: Institute for the Study of Labor.

KEDROSKY, P. and STANGLER, D., 2011. Financialization and Its Entrepreneurial Consequences. Kauffman Foundations Research Series: Firm Formation and Economic Growth.

KOSE, M.A., PRASAD, E., ROGOFF, K and WEI, S., 2006. Financial Globalization: A Reappraisal. IMF Staff Papers, 56(1), 8-62.

KRIPPNER, G.R., 2004. What is Financialization?. Mimeo. Los Angeles: University of California, Department of Sociology.

KRIPPNER, G.R., 2005. The financialisation of the American economy. Socio-Economic Review, 3(2), 173-208.

KRIPPNER, G.R., 2011. Capitalizing on Crisis: The Political Origins of the Rise of Finance. Cambridge: Harvard University Press.

KRISTAL, T., 2010. Good Times, Bad Times. Postwar Labor's Share of National Income in Capitalist Democracies. American Sociological Review, 75(5), 729-763.

DINÂMIA'CET - IUL, Centro de Estudos sobre a Mudança Socioeconómica e o Território ISCTE-IUL - Av, das Forças Armadas, 1649-026 Lisboa, PORTUGAL 
Evolution of the financial sector - three different stages:

Repression, development and financialisation

KUS, B., 2012. Financialisation and Income Inequality in OECD Nations: 1995-2007. The Economic and Social Review, 43(4), 477-495.

LAPAVITSAS, C., 2011. Theorizing financialization. Work, Employment and Society, 25(4), 611-626.

LAZONICK, W. and O'SULLIVAN, M., 2000. Maximising shareholder value: a new ideology for corporate governance. Economic and Society, 29(1), 13-35.

LEE, R., ClARK, G., POLLARD, J. and LEYSHON, A., 2009. The remit of financial geography - before and after the crisis. Journal of Economic Geography, 9(5), 723-747.

LEIVA, F.I. and MALINOWITZ, S., 2007. Financialization in the Americas: Evidence and Consequences. Mimeo. University at Albany and Universidad Nacional de Colombia.

LEVINE, R., 2005. Finance and Growth: Theory and Evidence. IN: AGHION, P. and DURLAUF, S.N., eds. Handbook of Economic Growth, Amsterdam: Elsevier, pp. 865-934.

LIN, K. and TOMASKOVIC-DEVEY, D., 2013. Financialization and U.S. Income Inequality, 1970 - 2008. American Journal of Sociology, 118(5), 1284-1329.

LUCARELLI, B., 2012. Financialization and Global Imbalances: Prelude to Crisis. Review of Radical Political Economics, 44(4), 429-447.

LUDVIGSON, S. and STEINDEL, C., 1999. How Important Is the Stock Market Effect on Consumption?. Economic Policy Review, 5(2), 29-51.

LUDWIG, A. and SLØK, T., 2001. The Impact of Changes in Stock Prices and House Prices on Consumption in OECD Countries. IMF Working Paper, N. ${ }^{\circ}$ 02/1. Washington: International Monetary Fund.

MCKINNON, R.I., 1973. Money and Capital in Economic Development. Washington: The Brookings Institution.

DINÂMIA'CET - IUL, Centro de Estudos sobre a Mudança Socioeconómica e o Território ISCTE-IUL - Av, das Forças Armadas, 1649-026 Lisboa, PORTUGAL 
Evolution of the financial sector - three different stages:

Repression, development and financialisation

MEHRA, Y.P., 2001. The Wealth Effect in Empirical Life-Cycle Aggregate Consumption

Equations. Federal Reserve Bank of Richmond Economic Quarterly, 87(2), 45-68.

MENKHOFF, L. and TOLKSDORF, N., 2001. Financial Market Drift: Decoupling of the Financial Sector from the Real Economy. Berlin: Springer.

MILLER, M.H., 1998. Financial markets and economic growth. Journal of Applied Corporate Finance, 11(3), 8-15.

ONARAN, Ö., STOCKHAMMER, E. and GRAFL, L., 2011. Financialization, income distribution and aggregate demand in the USA. Cambridge Journal of Economics, 35(4), 637661.

ORHANGAZI, Ö., 2008a. Financialization and the US Economy. Cheltenham: Edward Elgar Publishing Limited.

ORHANGAZI, Ö., 2008b. Financialisation and capital accumulation in the non-financial corporate sector: A theoretical and empirical investigation on the US economy: 1973-2003. Cambridge Journal of Economics, 32(6), 863-886.

ORSI, L. and SOLARI, S., 2010. Financialisation in Southern European economies. ICATSEM Working Paper, N. ${ }^{2}$. Bordeaux: Institutional Change and Trajectories of Socio-Economic Models.

PALLEY, T.I., 2004. Asset-based Reserve Requirements: Reasserting Domestic Monetary Control in an Era of Financial Innovation and Stability. Review of Political Economy, 16(1), 4358.

PALLEY, T.I., 2007. Financialisation: What it is and Why it Matters. PERI Working Paper, N. ${ }^{\circ}$ 153. Washington: Political Economy Research Institute.

PALLEY, T.I., 2012. From Financial Crisis to Stagnation: The Destruction of Shared Prosperity and the Role of Economics. Cambridge: Cambridge University Press.

DINÂMIA'CET - IUL, Centro de Estudos sobre a Mudança Socioeconómica e o Território ISCTE-IUL - Av. das Forças Armadas, 1649-026 Lisboa, PORTUGAL 
Evolution of the financial sector - three different stages:
Repression, development and financialisation

PERALTA, I.A. and ESCALONILLA, F.L., 2011. Financiarización, acumulación de capital y crecimiento salarial en la UE-15. Investigación Económica, 70(276), 125-162.

POWER, D., EPSTEIN, G. and ABRENA, M., 2003. Trends in the Rentier Income Share in OECD Countries, 2960-2000. PERI Working Paper, N. ${ }^{\circ}$ 58a. Washington: Political Economy Research Institute.

PRASAD, E.S., RAJAN, R. G. and SUBRAMANIAN, A., 2007. Foreign Capital and Economic Growth. NBER Working Paper, N. ${ }^{\circ}$ 13619. Cambridge: National Bureau of Economic Research.

RAJAN, R.G., 2010. Fault Lines: How Hidden Fractures Still Threaten the World Economy. Princeton: Princeton University Press.

RIOJA, F. and VALEV, N., 2004a. Finance and Sources of Growth at Various Stages of Economic Development. Economic Inquiry Journal, 42(1), 127-140.

ROUSSEAU, P.L. and WACHTEL, P., 2011. What is happening to the impact of financial deepening on economic growth. Economic Inquiry, 49(1), 276-288.

SAMUEL, C., 2000. Does shareholder myopia lead to managerial myopia? A first look. Applied Financial Economics, 10(5), 493-505.

SAWYER, M., 2013a. What Is Financialization?. International Journal of Political Economy, 42(4), 5-18.

SAWYER, M., 2013b. Bank-based versus market-based financial systems: a critique of the dichotomy. FESSUD Working Paper Series, N. ${ }^{\circ}$ 19. Leeds: University of Leeds.

SAWYER, M., 2014. Financial development, financialisation and economic growth. FESSUD Working Paper Series, N. ${ }^{\circ} 21$. Leeds: University of Leeds.

SAWYER, M., 2015. Financialisation, financial structures, economic performance and employment. FESSUD Working Paper Series, N. ${ }^{\circ}$ 93. Leeds: University of Leeds.

DINÂMIA'CET - IUL, Centro de Estudos sobre a Mudança Socioeconómica e o Território ISCTE-IUL - Av. das Forças Armadas, 1649-026 Lisboa, PORTUGAL 
Evolution of the financial sector - three different stages:

Repression, development and financialisation

SCHUMPETER, J., 1911. The Theory of Economic Development: An Inquiry into Profits,

Capital, Credit, Interest, and the Business Cycles. New Brunswick and London: Transaction Publishers.

SHAW, E.S., 1973. Financial deepening in economic development. New York: Oxford University Press.

SKOTT, P. and RYOO, S., 2008. Macroeconomic implications of financialization. Economics Department Working Paper Series, N. ${ }^{\circ} 41$. Amherst: University of Massachusetts.

SOENER, M. C., 2015. Why do firms financialize? Meso-level evidence from the US apparel and footwear industry, 1991-2005. Socio-Economic Review. Published online April 22.

STIGLITZ, J., 2012. The Price of Inequality: How Today's Divided Society Endangers Our Future. New York: W. W. Norton \& Company.

STOCKHAMMER, E., 2004a. Financialization and the slowdown of accumulation. Cambridge Journal of Economics. 28(5), 719-741.

STOCKHAMMER, E., 2009. Determinants of Functional Income Distribution in OECD Countries. IMK Studies, N. o 5/2009. Düsseldorf: Macroeconomic Policy Institute.

STOCKHAMMER, E., 2010. Financialization and the Global Economy. PERI Working Paper, N. ${ }^{\circ}$ 240. Washington: Political Economy Research Institute.

TOMASKOVIC-DEVEY, D., LIN, K. and MEYERS, N., 2015. Did financialization reduce economic growth?. Socio-Economic Review. Published online May 13.

VAN DER ZWAN, N., 2014. Making sense of financialization. Socio-Economic Review, 12(1), 99-129.

VAN TREECK, T., 2008. Reconsidering the Investment-Profit Nexus in Finance-Led Economies: an ARDL-Based Approach. Metroeconomica, 59(3), 371-404.

DINÂMIA'CET - IUL, Centro de Estudos sobre a Mudança Socioeconómica e o Território ISCTE-IUL - Av, das Forças Armadas, 1649-026 Lisboa, PORTUGAL 
Evolution of the financial sector - three different stages:

Repression, development and financialisation

$\overline{\text { VAN TREECK, T. and STURN, S., 2012. Income inequality as a cause of the Great Recession? }}$ A survey of current debates. Conditions of Work and Employment Series, N. ${ }^{\circ}$ 39. Switzerland: International Labour Office.

VERCELLI, A., 2013. Financialisation in a Long-Run Perspective. International Journal of Political Economy, 42(4), 19-46.

YELDAN, A.E., 2000. The Impact of Financial Liberalization and the Rise of Financial Rents on Income Inequality: The Case of Turkey. WIDER Working Paper, N. ${ }^{\circ} 206$. Helsinki: United Nations University, World Institute for Development Economics Research.

ZEZZA, G., 2008. U. S. Growth, the Housing Market, and the Distribution of Income. Journal of Post Keynesian Economics, 30(3), 375-401. 